\title{
Анализ влияния аминокислотных замен R177A, R181A, Y171F и Н309А на взаимодействие АР-эндонуклеазы человека с ДНК-субстратами
}

\author{
Бакман А.С.*, Кузнецов Н.А. \\ Институт химической биологии и фундаментальной медииины СО РАН, Новосибирск, Россия \\ *art-bakman@yandex.ru
}

Ключевые слова: АРЕ1, эксцизионная репарация оснований, метод остановленной струи

Мотивация и ичель: АР-эндонуклеаза человека (APE1) участвует в эксцизионной репарации оснований ДНК (BER), осуществляя гидролиз фосфодиэфирной связи в ДНК с 5'-стороны от апуринового/апиримидинового (AР) сайта. Помимо АРсайтов, APE1 способна распознавать в качестве субстрата некоторые модифицированные нуклеозиды (NIR-активность). Кроме того, фермент обладает 3'-фосфатазной, 3'-фосфодиэстеразной, 3'-5'-экзонуклеазной и эндорибонуклеазной активностями. Целью данной работы было установление роли аминокислотных остатков фермента R177, R181, Y171 и Н309 в распознавании и процессировании различных ДНК-субстратов.

Meтоды $и$ алгоритмы: Кинетику взаимодействия мутантных форм APE1, содержащих замены R177A, R181A, Y171F и H309A, с ДНК-дуплексами, содержащими синтетический аналог АР-сайта (F-сайт), исследовали методом остановленной струи с детекцией флуоресценции остатков триптофана белка и остатка 6-карбоксифлуоресцеина в составе FRET-пары в молекуле ДНКсубстрата. Сравнение активностей мутантных форм фермента по отношению к различным ДНК-субстратам проводилось с помощью электрофоретического разделения реакционной смеси в полиакриламидном геле.

Результаты: Было показано, что замены Y171F и Н309A значительно снижают АР-эндонуклеазную активность АРЕ1 за счет резкого уменьшения $\mathrm{k}_{\mathrm{cat}}$, при этом у фермента остается способность эффективно связываться с субстратом. Замена $\mathrm{R} 181 \mathrm{~A}$ приводит к снижению $\mathrm{k}_{\text {cat }}$ в 3 раза, а также к снижению стабильности комплексов фермента с субстратом и с продуктом, в результате чего наблюдается небольшое снижение общей активности APE1. Замена R177A не изменяет значение $\mathrm{k}_{\mathrm{cat}}$, но облегчает диссоциацию фермента из комплекса с продуктом, что приводит к небольшому повышению общей АР-эндонуклеазной активности. Изучение активностей по отношению к другим ДНК-субстратам показало, что замены R177A и R181A заметно снижают 3'-5'-экзонуклеазную активность фермента и немного снижают NIR-активность.

Заключение: Предстационарный кинетический анализ взаимодействия мутантных форм AРЕ1 с ДНК-субстратами, содержащими F-сайт, позволил прояснить роль аминокислотных остатков R177, R181, Y171 и Н309 в отдельных стадиях ферментсубстратного взаимодействия. Также проведен сравнительный анализ NIR- и 3'-5'экзонуклеазной активностей, позволяющий судить о роли данных остатков в субстратной специфичности APE1.

Благодарности: Работа поддержана грантом РНФ № 19-74-10034. 